Article

\title{
Strengthening Community Sense of Place through Placemaking
}

\author{
Peter J. Ellery ${ }^{1, *}$ and Jane Ellery ${ }^{2}$ \\ ${ }^{1}$ School of Architecture and the Built Environment, Deakin University, Geelong, VIC 3220, Australia; \\ E-Mail: peter.ellery@deakin.edu.au \\ ${ }^{2}$ College of Health, Ball State University, Muncie, IN 47306, USA; E-Mail: jellery@bsu.edu \\ * Corresponding author
}

Submitted: 31 January 2019 | Accepted: 21 March 2019 | Published: 30 June 2019

\begin{abstract}
The concept of community involvement and the effect that the act of "making" has on the community itself is a key consideration in the placemaking discussion (Project for Public Spaces, 2015a; Silberberg, Lorah, Disbrow, \& Muessig, 2013). From a historical perspective, community development has been placed in the hands of individuals who are considered experts in the creative process. This approach often results in targeted criticism of the proposed development by the host community and a lack of trust in the motives and priorities of the professionals involved (Nikitin, 2012) and diminishes community involvement in the development of public space, a practice that empowers communities and fosters a sense of place among community members. This article discusses the theoretical foundations of community participation and the value of coproduction in the planning and design process, explores the role of placemaking as a strategy for developing a host community's sense of place, and proposes a continuum of placemaking strategies based on Arnstein's ladder of citizen participation to increase the likelihood that a sense of place within the host community will be developed as an outcome of the planning and design process. This continuum is designed to help planning and design professionals better understand how they might include the community in a co-produced process and to highlight the degree to which a placemaking approach to community planning and design promotes a sense of place as an outcome of the process.
\end{abstract}

\section{Keywords}

community-centred design; community development; community participation; placemaking

Issue

This article is part of the issue "Public Space in the New Urban Agenda: Research into Implementation", edited by Michael W. Mehaffy (KTH Royal Institute of Technology, Sweden), Tigran Haas (KTH Royal Institute of Technology, Sweden), and Peter Elmlund (Axel and Margaret Ax:son Johnson Foundation, Sweden).

(C) 2019 by the authors; licensee Cogitatio (Lisbon, Portugal). This article is licensed under a Creative Commons Attribution 4.0 International License (CC BY).

\section{Introduction}

Sense of place is a concept that encapsulates the many different ways in which people form connections with the environments they occupy (Cross, 2001; Ruddick, 2014). Definitions for sense of place are primarily based on the context in which they are being examined and include: anthropological perspectives related to the symbolic relationship people have with a piece of land (Low \& Altman, 1992); environmental perspectives that describe the experience an individual has when in a particular setting (Low, 1992); geographical perspectives and the aesthetic, tactile, or emotional bonds individuals form with a geographical place or setting (Steele, 1981); historical perspectives or the connection individuals create through the presentation and repetition of events within a certain place (Tuan, 1974); and sociological perspectives that consider community attachment and local sentiment based on how individuals both understand and are oriented toward a place (Jackson, 1994). The National Academy of Sciences report Community and the Quality of Life (2002) notes that community is often used as a synonym for place and that creating a sense of place is important because it also develops a strong sense of 
community among those who live there. This report supports the work of others suggesting that sense of place or community is a form of social capital that shapes the residents' personal identities, fosters a degree of community member rootedness in a place, provides us with a measure of liveability for that place, and creates a sense of well-being within us (Australian Local Government Association, National Heart Foundation of Australia, \& Planning Institute of Australia, 2008; Junot, Paquet, \& Fenouillet, 2018; National Academy of Sciences, 2002).

Creating a sense of place has become an essential part of contemporary community planning and development practice and can be achieved through the use of participatory strategies and placemaking (Aravot, 2002; Friedmann, 2010; Madanipour, 2006; Mahjabeen, Shrestha, \& Dee, 2009). Bringing placemaking into the discussion, Project for Public Spaces ([PPS], 2015a) defines placemaking as the act of strengthening the connection between people and place through the creation of public spaces that act as a centre or focal point for the community. While an ambitious and optimistic goal, placemaking seeks to build or improve public spaces so that they also serve physical, cultural, and social objectives. These objectives include the promotion of public discourse, civic pride, neighbourhood connections, community health and safety, social justice, economic development, and environmental sustainability, to name a few (Silberberg, Lorah, Disbrow, \& Muessig, 2013).

Central to the tenet of placemaking is the transformation that occurs when the community members participating in the process, or host-community, are actively involved in that process. By having community members engage in the deliberative and communal processes associated with planning and developing public spaces, citizens assume a more active political voice and influential role in the revitalization of the landscape in which they live (Silberberg et al., 2013). This active involvement not only empowers community members but also nurtures community capacity and local leadership. Silberberg et al. (2013) note that placemaking creates a virtuous cycle and mutual stewardship between a community and its environment. Within this cycle, the community transforms and reshapes the place in which they live, while concurrently, the place is influencing and transforming the way in which the community exists within it.

This growing conversation around placemaking, community empowerment, and community sense of place is important because it suggests that the way in which change in communities takes place also has the potential to produce social benefits like the development of a sense of place within the community. Expanding upon this discussion, this article will investigate how placemaking has the potential to create a sense of place as an outcome of the planning and development process by exploring the question, can an understanding of the connection between placemaking and sense of place be used as a rationale for increasing citizen control during community change efforts?
This will be explored by summarizing findings related to participatory approaches as represented by diverse organizations in varied disciplines, highlighting the value seen when community members are at the forefront of community change processes, and connecting citizen power and community engagement to create a framework for thinking about a sense of place as an outcome for community change efforts. This understanding of the connection between engagement and sense of place that emerges will allow community planners and developers to embrace a coproduction process as more than just a way of developing spaces that meet the needs voiced by a host community. If effectively implemented, placemaking may be able to strengthen the community's tie to the places that are created and empower community members to take more active roles in managing and maintaining their environments and in thinking toward the future.

\section{Placemaking, Community Engagement, and Collaboration}

For many years, citizen participation has been encouraged as a feature of urban development processes. In 1969, Arnstein offered a visual metaphor for citizen participation (see Table 1) when describing a typology of eight levels of participation organized on the rungs of a ladder (Arnstein, 1969). The bottom rungs are manipulation and therapy and are identified as non-participatory practices. These only involve the community as spectators while providing the powerholders, or experts leading the process, the opportunity to educate and cure. Informing and consultation follow on the ladder. Progressing to this level of participation, identified as "tokenism", allows "the have-nots to hear and have a voice" in the process (Arnstein, 1969, p. 217). The fifth level on the ladder is placation, a higher level of tokenism where "the ground rules allow have-nots to advise, but retain for the powerholders the continued right to decide" (Arnstein, 1969, p. 217). The final three levels, partnership, delegated power, and citizen control, are all identified as providing genuine degrees of citizen power, ranging from negotiating rights to full managerial power. As such, they accord community members with varying degrees of decisionmaking ability in the planning and design process.

Community involvement has also been discussed and debated by many groups, including the Association for Public Participation (International Association for Public Participation, 2018). Their proposed spectrum of public participation offers five levels of community involvement that include inform, consult, involve, collaborate, and empower, with each practice level increasing the opportunity for community members to impact decision-making (see Table 2). The empower end of this continuum has a public participation goal of placing the final decisionmaking in the hands of the public and holds a promise that the professionals leading the project will then implement the decisions the community makes. 
Table 1. Adapted from Arnstein's Ladder for Citizen Participation (Arnstein, 1969).

8. Citizen Control

\begin{tabular}{ll}
\hline 7. Delegated Power & Citizen Power \\
6. Partnership &
\end{tabular}

5. Placation

4. Consultation

Tokenism

3. Informing

2. Therapy

1. Manipulation

Nonparticipation

Table 2. The spectrum of public participation types based on the degree to which the participation impacts decision making (International Association for Public Participation, 2018).

\begin{tabular}{|c|c|c|c|c|c|}
\hline & Inform & Consult & Involve & Collaborate & Empower \\
\hline $\begin{array}{l}\text { Public } \\
\text { Participation } \\
\text { Goal }\end{array}$ & $\begin{array}{l}\text { To provide the } \\
\text { public with } \\
\text { balanced and } \\
\text { objective } \\
\text { information to } \\
\text { assist them in } \\
\text { understanding the } \\
\text { problem, } \\
\text { alternatives, } \\
\text { opportunities } \\
\text { and/or solutions. }\end{array}$ & $\begin{array}{l}\text { To obtain public } \\
\text { feedback on } \\
\text { analysis, } \\
\text { alternatives } \\
\text { and/or decisions. }\end{array}$ & $\begin{array}{l}\text { To work directly } \\
\text { with the public } \\
\text { throughout the } \\
\text { process to ensure } \\
\text { that public } \\
\text { concerns and } \\
\text { aspirations are } \\
\text { consistently } \\
\text { understood and } \\
\text { considered. }\end{array}$ & $\begin{array}{l}\text { To partner with } \\
\text { the public in each } \\
\text { aspect of the } \\
\text { decision including } \\
\text { the development } \\
\text { of alternatives and } \\
\text { the identification } \\
\text { of the preferred } \\
\text { solution. }\end{array}$ & $\begin{array}{l}\text { To place final } \\
\text { decision making } \\
\text { in the hands of } \\
\text { the public. }\end{array}$ \\
\hline $\begin{array}{l}\text { Promise to } \\
\text { the Public }\end{array}$ & $\begin{array}{l}\text { We will keep you } \\
\text { informed. }\end{array}$ & $\begin{array}{l}\text { We will keep you } \\
\text { informed, listen } \\
\text { to and } \\
\text { acknowledge } \\
\text { concerns and } \\
\text { aspirations, and } \\
\text { provide feedback } \\
\text { on how public } \\
\text { input influenced } \\
\text { the decision. }\end{array}$ & $\begin{array}{l}\text { We will work with } \\
\text { you to ensure that } \\
\text { your concerns and } \\
\text { aspirations are } \\
\text { directly reflected } \\
\text { in the alternatives } \\
\text { developed and } \\
\text { provide feedback } \\
\text { on how public } \\
\text { input influenced } \\
\text { the decision. }\end{array}$ & $\begin{array}{l}\text { We will look to you } \\
\text { for advice and } \\
\text { innovation in } \\
\text { formulating } \\
\text { solutions and } \\
\text { incorporate your } \\
\text { advice and } \\
\text { recommendations } \\
\text { into the decisions } \\
\text { to the maximum } \\
\text { extent possible. }\end{array}$ & $\begin{array}{l}\text { We will } \\
\text { implement what } \\
\text { you decide. }\end{array}$ \\
\hline
\end{tabular}

An accompanying set of core values define the expectations for each of these participation levels in the planning and design process. These range from public participation being "based on the belief that those who are affected by a decision have the right to be involved in the decision-making process", to a promise that "the public's contribution will influence the decision" (International Association for Public Participation, 2019). Building from this model, the Clinical and Translational Science Award Consortium (2011) proposed a Community Engagement Continuum starting at outreach and extending to shared leadership. This conceptualization has each level (outreach, consult, involve, collaborate, and shared leadership) accompanied by an increasing level of community involvement, impact, trust, and communication flow.
One benefit highlighted by this health-related approach is that:

While community engagement may be achieved during a time-limited project, it frequently involvesand often evolves into-long-term partnerships that move from the traditional focus on a single health issue to address a range of social, economic, political, and environmental factors that affect health. (Clinical and Translational Science Awards Consortium, 2011, p. 7)

The concept of coproduction can also guide our perceptions on engagement and its ability to develop a sense of place within a community. Traditionally, public goods 
and services are "potentially produced by the regular producer and by those who are frequently referred to as the client" (Ostrom, 1996, p. 1073). In this process, the term client is considered to be passive and most often the entity being acted upon. Coproduction, however, "implies that citizens can play an active role in producing public goods and services of consequences to them" (Ostrom, 1996, p. 1073). Ostrom and her colleagues at the Workshop in Political Theory and Policy Analysis coined this term in the late 1970s while struggling with the dominant urban governance theories and policies related to massive decentralization. Their studies of metropolitan police services failed to uncover a single instance where a centralized department was able to provide better direct services or lower costs to neighbourhoods (Ostrom, 1996). They also realized that:

The production of a service, as contrasted to a good, was difficult without the active participation of those supposedly receiving the service. If students are not actively engaged in their own education, encouraged and supported by their family and friends, what teachers do may make little difference in the skills students acquire. If citizens do not report suspicious events rapidly to a police department, there is little that department can do to reduce crime in an area or solve the crimes that occur. (Ostrom, 1996, p. 1073)

In a collaborative learning system, and with the role of "experts" reconsidered to include community members as experts on their communities, the value proposition of coproduction can be reimagined as progressing from professionals engaging with communities to communities engaging with professionals (Goerner, 2007).

Cross-sectoral collaboration also plays a role in working to coproduce change. Working with multi-sectoral partners and the community to coproduce goods, services and policies can provide new and additional perspectives to the planning and design process, can help with the identification and addressing of community needs, and can aid in the development of planning and designing solutions that are best suited to addressing those needs (The Public Health National Center for Innovations, 2018). Recent work from Climate Interactive, a group using systems analysis to help people address climate change, introduced the practice of "multi solving". When multi solving, "people pool expertise, funding, and political will to solve multiple problems with a single investment of time and money" (Swain, 2018, p. 1). While there are different multi solving approaches, three key principles and three practices emerged from the related research. These three principles include: 1) everyone matters, and everyone is needed; 2 ) we can succeed by addressing tough problems in an integrated fashion; 3) large solutions start small and growth results from learning and connecting. The three practices involve: 1) welcoming; 2) learning and documenting; and 3) storytelling (Swain, 2018). Placemaking, citizen sci- ence, and community development, like many other collaborative approaches, typically value these same principles and practices, and along with multi solving will be critical in addressing many of the global issues that have been identified in the United Nation's Sustainable Development Goals (United Nations, 2016).

The ideas presented in this section are not new. Contemporary organizations continue to build on the work of Jane Jacobs (1961), Jan Gehl (1971), William "Holly" Whyte (1980), and other urbanists who, over the years, have advocated for bringing the public into the design process. The voice of the community is regularly sought at the level of tokenism but fewer examples are available that represent true levels of involvement. While not all projects require authentic community participation, and community dialogue and engagement can be time consuming and messy, many initiatives would gain value from spending the time needed to move further up Arnstein's Ladder and further toward citizen control and co-production.

\section{The Value Proposition}

Antonovsky (1979) discusses at length the value of being involved as a participant in the processes that shape both our destiny and our daily experiences. Participatory approaches are now an integral part of many planning processes and have the potential to positively impact an individual's sense of coherence (SOC). This involvement exposes community members to new challenges and allows them to continue to develop their skills and relationships. Typically, the outcomes and products from these person-centred initiatives closely match the needs and interests of the individuals who were involved in the process, rather than the needs and interests of those who were not included in the process. This approach is also highlighted in IDEO's Field Guide to Human-Centred Design and emphasizes the importance of person/human involvement in the design process:

Embracing human-centred design means believing that all problems, even the seemingly intractable ones like poverty, gender equality, and clean water, are solvable. Moreover, it means believing that the people who face those problems every day are the ones who hold the key to their answer. Human-centred design offers problem solvers of any stripe a chance to design with communities, to deeply understand the people they're looking to serve, to dream up scores of ideas, and to create innovative new solutions rooted in people's actual needs. (IDEO, 2015, p. 9)

Examples of the value community engagement in placemaking can be seen in projects like the revitalization of Congress Square in Portland, Maine (Cronstein \& LaCasse, 2014). Congress Square was developed through an Urban Development Action Grant in the early 1980s and was designed to add vitality to the city as a public 
space. Through the 1980s and 1990s, the park was actively programmed with events like dances, movies and concerts, and became a gathering place for local residents and visitors to the city. As public and private investment in the park declined, the space and its use deteriorated leaving the park looking unkept, unwelcoming and unsafe (see Figure 1).

By the early 2000s, the park was on the verge of being sold by the city, and a grassroots organization called the Friends of Congress Square Park was formed bring the community together and revitalize the park. The group raised money, attention, and a great deal of interest in the park through the use of signs like "I want...in Congress Square" that were left around the city, and that the general public could write on all to share their aspirations for the park's future. The community group then started cleaning up the park and adding amenities (see Figure 2).

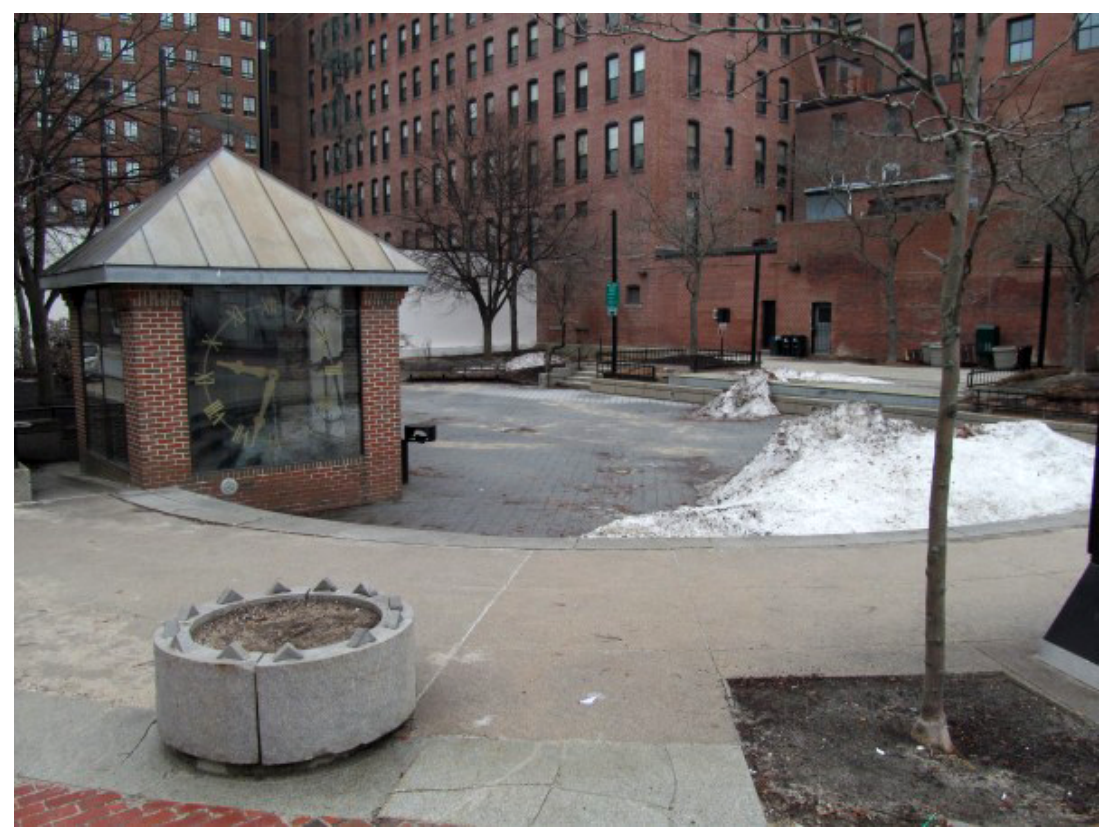

Figure 1. Congress Park, Portland, Maine, before community interventions in the early 2000s (image courtesy of Project for Public Spaces, retrieved from https://www.pps.org/article/the-story-of-congress-square-park-how-a-derelict-plaza-got-anew-identity-downtown).

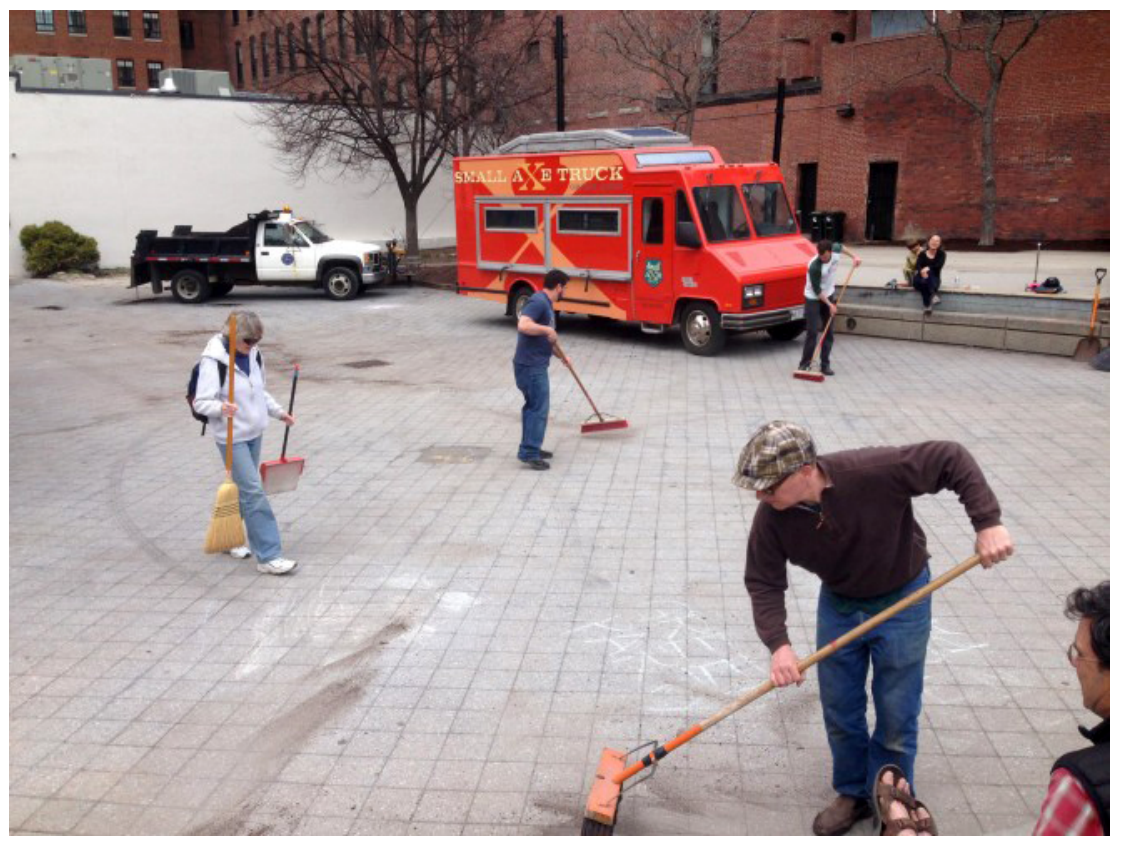

Figure 2. Friends of Congress Park during the park clean-up and revitalization of the park (image courtesy of Project for Public Spaces, retrieved from https://www.pps.org/article/the-story-of-congress-square-park-how-a-derelict-plaza-got-anew-identity-downtown). 
These changes were further enhanced through the addition of moveable furniture, free $\mathrm{WiFi}$, and access to food trucks. In time, more and more people began coming to the park just to site outside, enjoy a cup of coffee, read the paper, or even work from their computers. Since then, the park has grown in popularity and use, and is now beginning to be programmed again with events and activities that keep the park alive and meaningful to the community. These events include dancing, live concerts, movie nights, and even hosted a live telecast of the world cup in soccer (see Figure 3). As community member Maureen Hannigan explained:

I especially loved the swing dancing event. It was magical. Everyone was dancing-hotel guests, kids from the neighbourhood, people just passing by stopped to listen or dance. It was so moving. I almost got out of my wheelchair and started dancing too! I also loved the world cup soccer games. There was such a diverse mix of people. Congress Square Park knocks down social walls and brings the community together. It's a village. (Cronstein \& LaCasse, 2014)

PPS has also noted that the Friends of Congress Park have brought life back to the park through the use of lighter, quicker and cheaper (LQC) approaches to revitalizing the space and that has given them the opportunity to assess and reassess their success, first with art installations, movable furniture and $\mathrm{WiFi}$, and then with food trucks events, and vegetation and tree planters as they have moved forward, and now this community group is looking to extend past the parks physical boundaries as they consider work and other projects they can engage in.
This community engaged, placemaking approach to design utilizes a three-step process that involves inspiration, ideation, and implementation phases. The inspiration phase encourages designers to interact with the community in a number of ways including group interviews, community activities, and immersion within the community. Each of these techniques helps gather relevant information from the community in ways that do not appear intrusive to the community members. These techniques also provide a sense of empathy and understanding for the community. As the Field Guide to Human-Centred Design states, "the Inspiration phase is about learning on the fly, opening yourself up to creative possibilities, and trusting that as long as you remain grounded in desires of the communities you're engaging, your ideas will evolve into the right solutions" (IDEO, 2015 , p. 30). This matching of the design solution with community's desires and needs addresses the meaningful aspect of Antonovsky's SOC within the space undergoing the change.

Placemaking, as proposed by PPS, also embraces a participatory approach to change and offers this description:

Placemaking refers to a collaborative process by which we can shape our public realm in order to maximize shared value. More than just promoting better urban design, Placemaking facilitates creative patterns of use, paying particular attention to the physical, cultural, and social identities that define a place and support its ongoing evolution.

With community-based participation at its centre, an effective Placemaking process capitalizes on a local

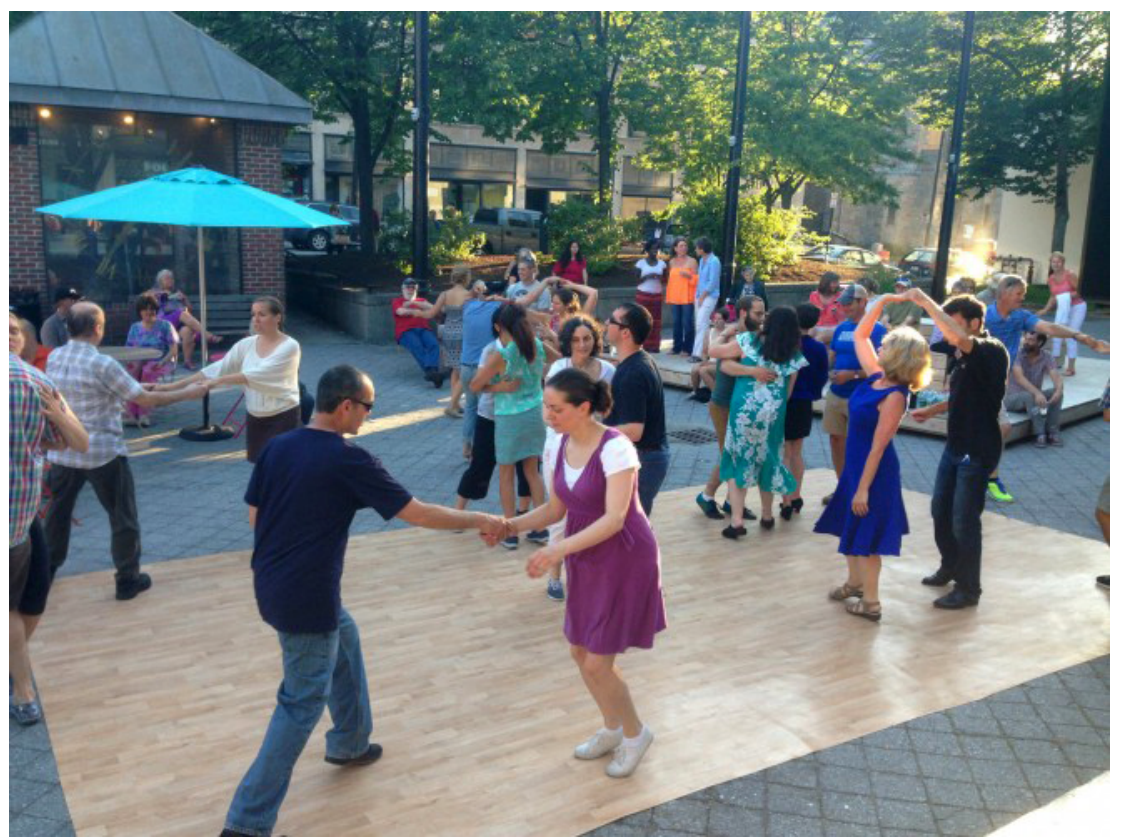

Figure 3. Swing dancing in Congress Park Square, Portland, Maine (image courtesy of Project for Public Spaces, retrieved from https://www.pps.org/article/the-story-of-congress-square-park-how-a-derelict-plaza-got-a-new-identitydowntown). 
community's assets, inspiration, and potential, and it results in the creation of quality public spaces that contribute to people's health, happiness, and wellbeing. (PPS, 2015b, paras 1-2)

The value of participation is further expressed in the first of the Eleven Principles for Creating Great Places presented by PPS (2015a). In this report, PPS notes that the community should be considered the expert when it comes to public space design, and that good design starts with the identification of people in the community who can provide insights into how an area functions and the issues that most impact the people using the space. Most critically, PPS suggests that this process fosters a sense of community ownership in the project that can benefit both the project sponsor and the community (PPS, 2015a).

Strategies promoting best practices in placemaking have been well described by Silberberg and her colleagues (Silberberg et al., 2013). They contend that the act of placemaking increases a community's stewardship and responsibility for a place. For example, communities might become involved in placemaking through the painting of murals and artwork on walls, or by setting up small businesses in the space to promote its use and value. Communities can also become involved in the design of space by allowing those using the space to arrange objects and furniture so that it best meets their needs. Flexible spaces using portable furniture, plants, and features allow the community to set up spaces that are meaningful, manageable, and comprehensible to them. Designers can then note the activities and environmental arrangements that have been created by the com- munity as they look to more permanent design features and arrangements for that environment, or conversely, leave the space flexible and adaptable so that the community is able to continue using the space in ways that meet many different demands and needs.

Each of these techniques gives the community a greater SOC by allowing them to have greater control over the purpose, arrangement, and value of the space they create. In turn, this involvement leads to a number of benefits including an increased political voice for the community, greater control over the direction of change in the community, and a greater sense of stewardship and responsibility by the community for the changes that have been created (Silberberg et al., 2013). An example of this increased stewardship can be seen in Muncie, Indiana, with the Whitely Community Council's gradual assumption of more and more responsibility for each project that they are involved in.

While still in its infancy, the Whitely Community Council began restoration on a historically significant civil rights church known as the Schaffer Chapel. While funding had been made available for the restoration of the church roof and siding, little money had been set aside for other aspects of the restoration such as parking or landscaping. To improve the church's image from the street on the northwest corner of the church, the council leadership worked with Ball State University and the Minnetrista Cultural Centre in 2014 to establish a planting plan and the obtain flowers needed for the garden at little cost to the community. A community work day was held and in the space of one day, the garden was installed (see Figure 4).

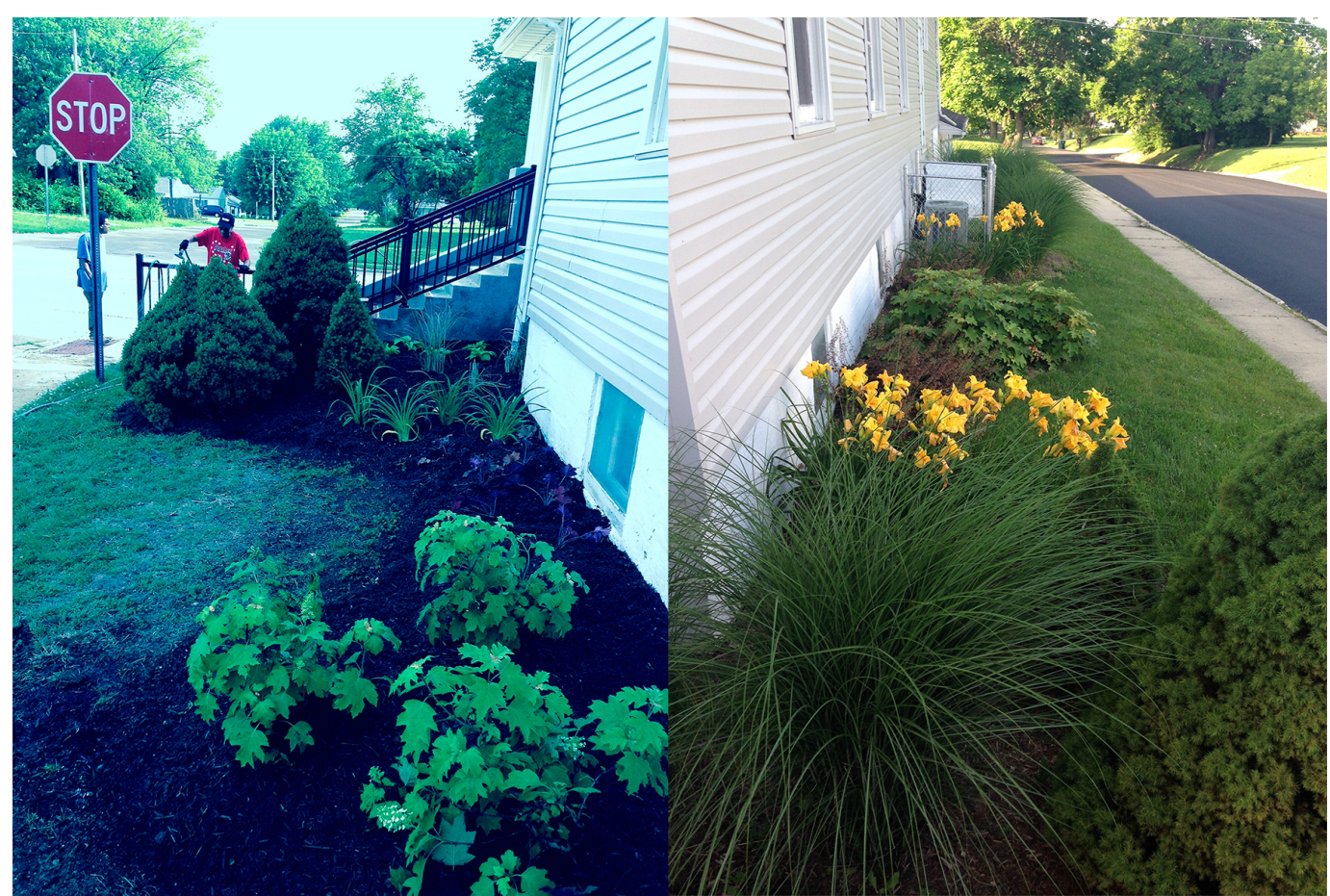

Figure 4. Schaffer Chapel northwest garden at the completion of the installation in June of 2014 (left), and in July of 2015 (right; images courtesy of the authors). 
Emboldened by their success and the appearance of the garden on the northwest side of the church, the council again sought the help of Ball State University to obtain ideas and designs for an accessibility ramp, a parking area, and further vegetation for the east side of the church. With the help of the Muncie City council who laid the surface of the parking area as part of a training program for their workers, and some fund raising among the now growing Whitely Community Council membership, this second part of the landscape restoration process was successfully completed in 2015 (see Figure 5). Since then, the Whitely Community Council has worked with Ball State University to create a museum dedicated to the civil rights movement in Muncie and Indiana in the Schaffer Chapel (2016-2017), raised the funds and had to solar panels installed on the church in 2017, worked with the Muncie City Council in the removal of blighted properties in the Whitely neighbourhood (2016-2018) and have now acquired a former manufacturing site with the intention of turning into a community food pantry. Each of these progressive steps forward has seen the Whitely Community Council grow in numbers and become more independent in terms of their ability to address Whitely Community Needs and issues, without having to depend upon outside funding or city planning and development priorities.

\section{Using Placemaking to Create a Sense of Place}

The degree to which a sense of place is developed within a host community is influenced by the degree to which the community is engaged and responsible for the out- comes in the planning and development process. However, community engagement and participation is often contingent upon a number of other factors like the community's prior history of involvement in similar initiatives, the types of community involvement and participants needed, the level of planning, time, and resources that can be committed to community involvement and participation, the types of activities and decisions local participants would need to undertake, and the level of motivation or desire community members have to participate in the project (Burton et al., 2004; Goodlad, Burton, \& Croft, 2005). As such, community involvement in any planning and design process varies to some degree due to the goals and objectives of the activity needing to be achieved, the selection of appropriate community members and activities that can meet best these objectives, and the level of standards that need to be established for these activities (Burton et al., 2004). This suggests that while community involvement in placemaking promotes a sense of place among participants, the way in which the community participates may vary. In turn, the degree to which a sense of place is developed from the planning and design process could also vary.

Arnstein (1969) notes many different ways in which citizen participation can be incorporated into the planning and development process, and these levels of community participation and involvement can be viewed from low to high in a linear order. As placemaking requires community involvement and participation to occur at some level of decision-making, the lowest rung on Arnstein's ladder that could be considered a placemaking process is the level of partnership. At this level

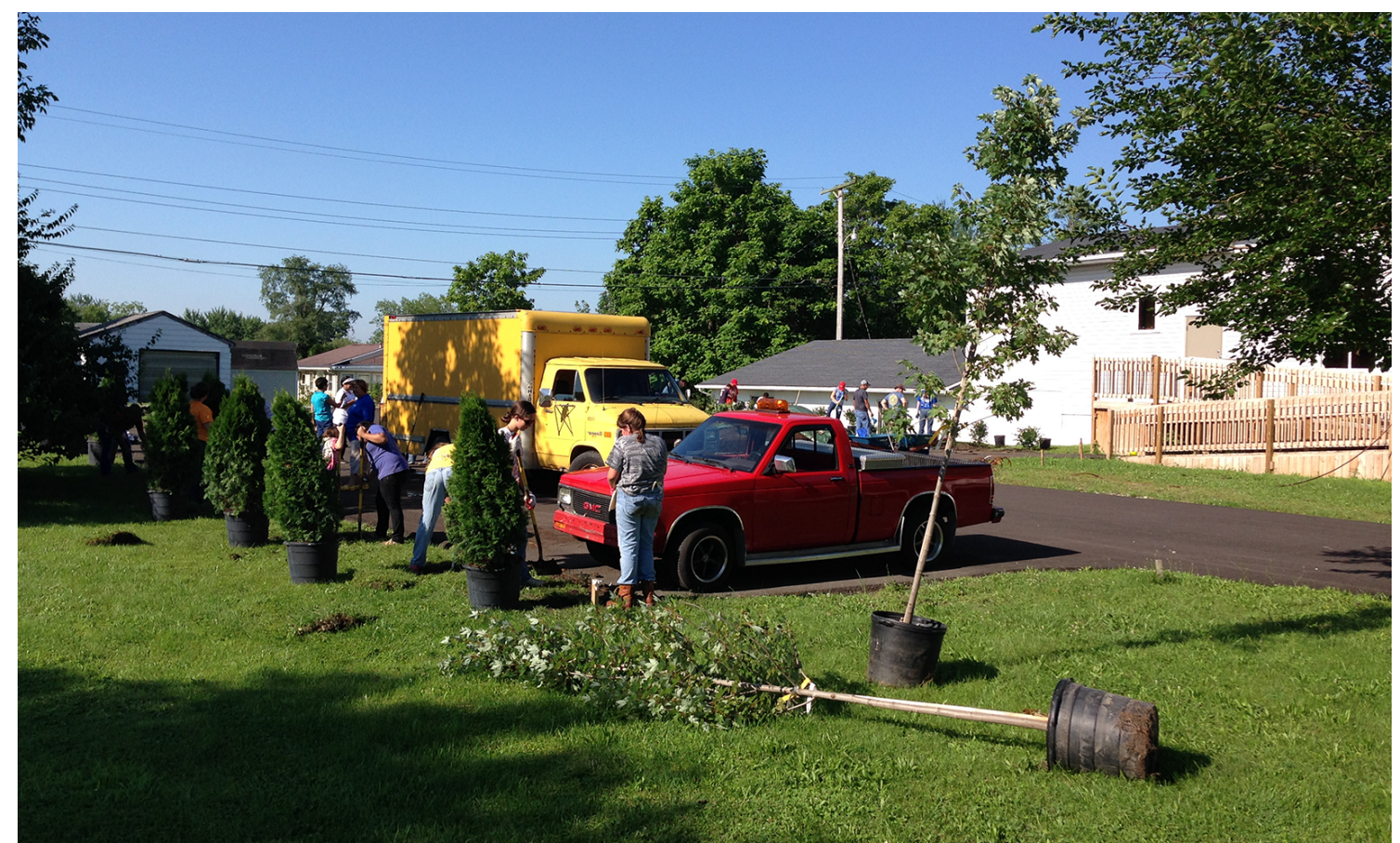

Figure 5. Installation of the vegetation, parking and church access ramp on the east side of the Schaffer Chapel in the Whitely Community in Muncie, Indiana (images courtesy of the authors). 
of community-centred involvement, the planning and design process is still primarily organized and led by the design professionals in the partnership, but with the community influencing project outcomes through contributions to, and negotiation with, these traditional powerholders (Arnstein, 1969). However, this level of community involvement and responsibility in the planning and design process is the least of the three citizen participation levels proposed in Arnstein's ladder and the least likely to result in encouraging a sense of place within the host-community (see Figure 6).

In contrast, community involvement and participation at the level of citizen control has the greatest potential to promote a strong sense of place within the host community as an outcome of the planning and design process. At this level of participation, community leaders are empowered to use the resources and information available to them as they see fit. In this role, the community makes decisions during the planning and design process that best meets their needs and uses professional design personnel and services in a consultative role. This level of participation is a "communitydriven" placemaking strategy and provides the host community with complete control of the planning process outcomes. This placemaking strategy requires a considerable commitment in terms of time and resources on the part of the community, but this additional community commitment produces the highest likelihood that a sense of place will result within the host-community and that proposed changes will be actually take place and be useful. Between these two placemaking endpoints lie a continuum of community involvement and placemaking strategies that, to varying degrees, can promote a sense of place. For example, planners can involve community members in charrettes and actual planning design activities, allow community members to review and critique design ideas through community reviews of planning proposals, and even use community members to assist with the installation or construction of the proposed develop- ment. Each of these activities helps foster the connection a community has with the place in which it inhabits and promotes a sense of place among the community members. Additionally, community members could also be involved in the construction processes alongside qualified professionals who currently live in the community, or perhaps through the donation of construction materials or landscaping plants. Ultimately, community members may take on leadership roles in the collection of planning data, or the organization of committees during the planning process. Each successive level of involvement and responsibility the community undertakes during the planning and design process serves to further strengthen the ties and connections the community has with the place being created. This increases the likelihood that a strong sense of place will be developed within the hostcommunity as a result.

\section{Conclusion}

The importance of community participation in the planning and development process has been well established in the literature. From Arnstein's (1969) pivotal work describing the range of citizen participation levels that could be used in the planning process, to modern day organizations like the Australian Citizen Science Association (Australian Citizen Science Association, 2019) and the International Association for Public Participation (International Association for Public Participation, 2016) that promote citizen involvement in community projects, civic engagement has been shown to enhance project outcomes (Aboelata, Ersoylu, \& Cohen, 2011; Selman, 2004), benefit the host communities in a variety of different ways (Aboelata et al., 2011; Goodlad et al., 2005; Silberberg et al., 2013), and increase the legitimacy of the firm and professional working with the community (Bowen, Newenham-Kahindi, \& Herremans, 2010). While the value of this community involvement is not always fully understood or appreciated by planning and

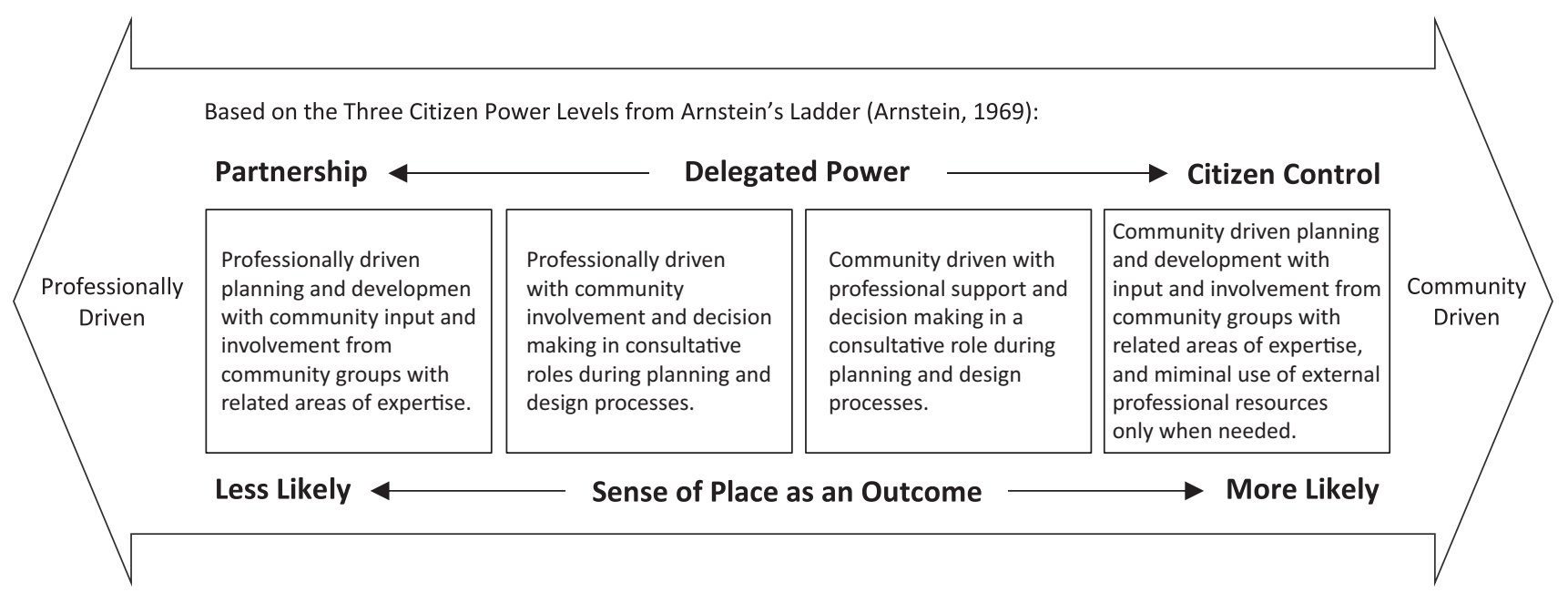

Figure 6. A proposed continuum of community participation and involvement in placemaking and the impact on the participant's development of a sense of place. 
development practitioners, most contemporary projects now incorporate an approach that includes community participation to some degree in the planning and development process.

As we continue to explore community engagement within the planning and development process, reinvisioning Arnstein's original ladder by expanding and analyzing Citizen Power levels and exploring citizen involvement from a coproduction perspective can provide a starting point (Bovaird, 2007). Given the positive association between the Citizen Power levels of participation and the concept of sense of place, more research and analysis is needed to fully understand how this relationship can be enhanced and the degree to which the types of engagement and decision making responsibilities given to the community influences outcomes. The model offered in this article is a step toward the reframing of Citizen Power levels in terms of the degree to which the decision making process is either professionally or community driven. From this perspective, a continuum of community engagement options based on coproduction is offered, with the potential for these options to further promote the psychological and social ties that enhance community resilience and bind community members together (Sanders \& Stappers, 2008; Stelzle, Jannack, \& Rainer Noennig, 2017).

Recent studies related to placemaking also offer a number of important perspectives about community involvement in the planning and development process. Placemaking emphasizes the importance of community engagement and decision making in and suggests that this form of engagement fosters an intrinsic connection and sense of identity between the community and place in which they live (Silberberg et al., 2013). This connection, or sense of place, is important because it empowers communities to pursue future changes, promotes the community's political voice, and fosters community stewardship for the environment in which they live. These placemaking benefits, while they may not be as significant for professionals in terms of planning and development outcomes, may be crucial to communities in rural or declining city neighbourhoods that are either too small or that lack the funding or resources needed to undertake community change projects. As such, using a planning approach that fosters sense of place as an outcome of the community's participation in the process has the potential to create long-term benefits that can serve the community in diverse ways in the future. With ongoing participation and community engagement, these same small and underrepresented rural and inner city communities may be empowered to initiate incremental changes within their neighborhoods at an ever increasing scale over time, with a greater degree of independence, at lower levels of cost to develop and implement, and with professional services used in consultative roles rather than as the drivers. This incremental approach can help communities avoid the need for larger and more expensive change projects, allow communities to respond quickly to changes when they are needed, and allow communities to implement change within their fiscal capacity. These can all evolve while continuing to foster and strengthen the community's sense of place.

\section{Conflict of Interests}

The authors declare no conflict of interests for this article.

\section{References}

Aboelata, M. J., Ersoylu, L., \& Cohen, L. (2011). Designing and building for health, well-being, and sustainability. in a. I. Dannenberg, H. Frumkin, \& R. J. Jackson (eds.), Making healthy places (p. 441). Washington, DC: Island Press. Retrieved from https://link.springer.com/ content/pdf/10.5822\%2F978-1-61091-036-1.pdf

Antonovsky, A. (1979). Health, stress and coping. San Francisco, CA: Jossey-Bass Publishing.

Aravot, I. (2002). Back to phenomenological placemaking. Journal of Urban Design, 7(2), 201-212. https:// doi.org/10.1080/135748002200001223

Arnstein, S. R. (1969). A ladder of citizen participation. Journal of the American Planning Association, 35(4), 216-224. https://doi.org/10.1080/ 01944366908977225

Australian Citizen Science Association. (2019). What is citizen science. Citizen Science Association. Retrieved from https://citizenscience.org.au/who-we-are

Australian Local Government Association, National Heart Foundation of Australia, \& Planning Institute of Australia. (2008). Healthy spaces and places: Towards a national planning guide. Retrieved from https:// www.planning.org.au/documents/item/189

Bovaird, T. (2007). Beyond engagement and participation: User and community coproduction of public services. Public Administration Review, 67(5), 846-860. https://doi.org/10.1111/j.1540-6210.2007.00773.x

Bowen, F., Newenham-Kahindi, A., \& Herremans, I. (2010). When suits meet roots: The antecedents and consequences of community engagement strategy. Journal of Business Ethics, 95(2), 297-318. https:// doi.org/10.1007/s10551-009-0360-1

Burton, P., Croft, J., Hastings, A., Slater, T., Goodlad, R., Abbott, J., \& Macdonald, G. (2004). What works in community involvement in area-based initiatives? National Archives. Retrieved from https://webarchive.nationalarchives.gov.uk/ 20110218141428/http://rds.homeoffice.gov.uk/ rds/pdfs04/rdsolr5304.pdf

Clinical and Translational Science Awards Consortium. (2011). Principles of community engagement. Public health. Farnham: National Institutes of Health.

Cronstein, J., \& LaCasse, B. (2014). The story of Congress Square Park: How a derelict plaza got a new identity downtown. Project for Public Spaces. Retrieved from https://www.pps.org/article/the-story-of-congress- 
square-park-how-a-derelict-plaza-got-a-newidentity-downtown

Cross, J. (2001). What is sense of place? Paper presented at the 12th Headwaters Conference, Western State College, Gunnison, Colorado, USA. Retrieved from https://www.researchgate.net/publication/ 282980896_What_is_Sense_of_Place

Friedmann, J. (2010). Place and place-making in cities: A global perspective. Planning Theory and Practice, 11(2), 149-165. https://doi.org/10.1080/ 14649351003759573

Gehl, J. (1971). Life between buildings. Washington, DC: Island Press.

Goerner, S. G. (2007). Today's Copernican flip: How putting collaborative learning at the hub of human evolution improves our chances of survival. Systems Research and Behavioral Science, 24, 481-491. https://doi.org/10.1002/sres.849

Goodlad, R., Burton, P., \& Croft, J. (2005). Effectiveness at what? The processes and impact of community involvement in area-based initiatives. Environment and Planning C: Government and Policy, 23(6), 923-938. https://doi.org/10.1068/c45m

IDEO. (2015). The field guide to human centered design. Design. Retrieved from http://www.designkit. org/resources/1

International Association for Public Participation (2016). Welcome to IAP2 Australasia. IAP2. Retrieved from https://www.iap2.org.au/Home

International Association for Public Participation. (2018). IAP2 Spectrum of public participation. IAP2. Retrieved from https://cdn.ymaws.com/www.iap2. org/resource/resmgr/pillars/Spectrum_8.5x11_ Print.pdf

International Association for Public Participation. (2019). IAP2 core values. IAP2. Retrieved from https://www. iap2.org/page/corevalues

Jackson, J. B. (1994). A sense of place, a sense of time. New Haven, CT: Yale University Press.

Jacobs, J. (1961). The death and life of great American cities. New York, NY: Random House.

Junot, A., Paquet, Y., \& Fenouillet, F. (2018). Place attachment influence on human well-being and general proenvironmental behaviors. Journal of Theoretical Social Psychology, 2, 49-57. https://doi.org/10.1002/ jts5.18

Low, S. M. (1992). Symbolic ties that bind: Place attachment in the Plaza. In I. Altman \& S. M. Low (Eds.), Place attachment (pp. 165-186). New York, NY: Plenum Press.

Low, S. M., \& Altman, I. (1992). Introduction. In I. Altman \& S. Low (Eds.), Place attachment (pp. 1-12). New York, NY: Plenum Press.

Madanipour, A. (2006). Roles and challenges of urban design. Journal of Urban Design, 11(2), 173-193. https://doi.org/10.1080/13574800600644035

Mahjabeen, Z., Shrestha, K. K., \& Dee, J. J. a. (2009). Rethinking community participation in urban plan- ning: The role of disadvantaged groups in Sydney metropolitan strategy. The Australasian Journal of Regional Studies, 15(1), 45. Retrieved from http://www.anzrsai.org/system/files/f8/f4/f51/f52/ o289/Mahjabeen.pdf

National Academy of Sciences. (2002). Community and quality of life: Data needs for informed decision making. Washington, DC: National Academy of Science. Retrieved from http://nap.edu/10262

Nikitin, C. (2012). Collaborative, creative placemaking: Good public art depends on good Public Spaces. Project for Public Spaces. Retrieved from https://www.pps.org/article/collaborative-creativeplacemaking-good-public-art-depends-on-goodpublic-spaces

Ostrom, E. (1996). Crossing the great divide: Coproduction, synergy, and development. World Development, 24(6), 1073-1087. https://doi.org/10.1016/ 0305-750X(96)00023-X

Project for Public Spaces. (2015a). Eleven principles for creating community places. Project for Public Spaces. Retrieved from http://www.pps.org/reference/ 11steps

Project for Public Spaces. (2015b). What is placemaking. Project for Public Spaces. Retrieved from http:// www.pps.org/reference/what_is_placemaking

Ruddick, S. (2014). Diverse conceptions of people, place and space. In J. J. Gieseking, W. Mangold, C. Katz, S. Low, \& S. Saegert (Eds.), The people, place and space reader (p. 446). London: Routledge.

Sanders, E., \& Stappers, P. J. (2008). Co-creation and the new landscapes of design. CoDesign, 4(1), 5-18. https://doi.org/10.1080/15710880701875068

Selman, P. (2004). Community participation in the planning and management of cultural landscapes. Journal of Environmental Planning and Management, 47(3), 365-392. https://doi.org/10.1080/ 0964056042000216519

Silberberg, S., Lorah, K., Disbrow, R., \& Muessig, A. (2013). Places in the making: How placemaking builds places and communities. Boston, MA: MIT. Retrieved from http://dusp.mit.edu/cdd/project/ placemaking

Steele, F. (1981). The sense of place. Boston, MA: CBI Publishing Company, Inc.

Stelzle, B., Jannack, A., \& Rainer Noennig, J. (2017). Co-design and co-decision: Decision making on collaborative design platforms. Procedia Computer Science, 112, 2435-2444. https://doi.org/10.1016/j. procs.2017.08.095

Swain, E. (2018). The magic of 'multisolving'. Stanford Social Innovation Review. Retrieved from https://ssir. org/articles/entry/the_magic_of_multisolving\#

The Public Health National Center for Innovations. (2018). Multi-sector partnerships and innovation. PHNCI Public Health Journal. Retrieved from https:// phnci.org/journal/multi-sector-partnerships-andinnovation 
Tuan, Y.-F. (1974). Topophilia: A study of environmental perception, attitudes, and values. New York, NY: Columbia University Press.

United Nations. (2016). 17 goals to transform our world.
United Nations. Retrieved from https://www.un.org/ sustainabledevelopment

Whyte, W. (1980). The social life of small urban spaces. New York, NY: Project for Public Spaces.

\section{About the Authors}

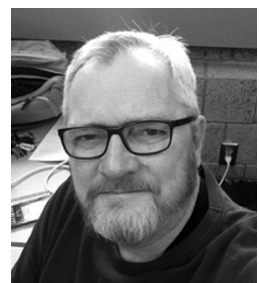

Peter J. Ellery is a Senior Lecturer in the School of Architecture and the Built Environment at Deakin University, where he combines his past education and work experience in health and landscape architecture to develop socially, economically, and environmentally regenerative communities using community-centered and engaged, collaborative design processes. His current interests are centered on the development of landscapes as educational, social and economic opportunities in developing nations, and how these landscapes can be used to foster thriving communities.

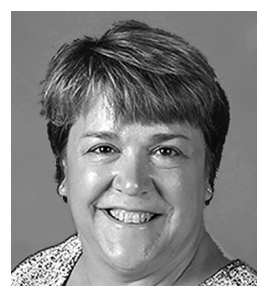

Jane Ellery, PhD, Assistant Professor of Wellness Management, Ball State University, and Senior Fellow, Project for Public Spaces, works at the intersection of Place, Health, and the Economy by focusing on collaborative change efforts, participatory approaches, and community-centred processes. After two decades working in prevention-related roles, Jane shifted from pathogenic interventions designed to keep people from getting sick to salutogenic initiatives that encourage engagement and living life to its fullest. 